\title{
Composition and ecological patterns of snake assemblages in an Amazon-Cerrado Transition Zone in Brazil
}

\author{
Leandra C. Pinheiro', Pedro S. Abe', Youszef O. C. Bitar', \\ Luiz P. P. Albarelli² \& Maria C. Santos-Costa'
}

1. Pós-Graduação em Zoologia , Universidade Federal do Pará/ Museu Paraense Emílio Goeldi, Rua Augusto Corrêa, 01, Guamá, 66075-1 10 Belém, Pará, Brazil.
(mcsc64@gmail.com)
2. Instituto Brasileiro do Meio Ambiente e dos Recursos Naturais Renováveis (IBAMA).

\begin{abstract}
The present study encompasses the species composition and ecological characteristics of the snake community in a Cerrado-Amazon transition zone in Midwest of Brazil (state of Mato Grosso). The data were collected during six excursions to the "Tanguro" (study area) by visual encounter survey, pitfall traps with drift fences and non-systematic sampling. We collected 194 specimens, distributed in 34 species, 26 genera, and eight families. The most abundant species were Crotalus durissus Linnaeus, $1758(\mathrm{n}=50)$, Philodryas olfersii (Lichtenstein, 1823) $(\mathrm{n}=15)$, Philodryas nattereri Steindachner, $1870(\mathrm{n}=13)$, Xenodon rabdocephalus (Wied, 1824) $(\mathrm{n}=12)$, Lachesis muta (Linnaeus, 1766) $(\mathrm{n}=10)$ and Erythrolamprus almadensis (Wagler, 1824) $(\mathrm{n}=10)$. The composition of species found here represents a combination of Cerrado and Amazonian savanna fauna.
\end{abstract}

KEYWORDS. Squamata, Amazon rainforest, savanna, community, ecotone.

RESUMO. Composição e padrões ecológicos da assembleia de serpentes em uma zona de transição Amazônia-Cerrado no Brasil. Avaliamos neste estudo a composição de espécies e características ecológicas de uma comunidade de serpentes em área de transição Cerrado-Amazônia, no Centro-Oeste do Brasil (Estado do Mato Grosso). Coletamos os dados durante seis expedições para "Tanguro" (área de estudo) através dos métodos de procura visual, armadilhas de interceptação e queda e encontros ocasionais. Registramos 194 espécimes, distribuídas em 34 espécies, 26 gêneros e oito famílias. As espécies mais abundantes foram Crotalus durissus Linnaeus, 1758 ( $\mathrm{n}=50)$, Philodryas olfersii (Lichtenstein, 1823$)$ ( $\mathrm{n}$ $=15)$, Philodryas nattereri Steindachner, $1870(\mathrm{n}=13)$, Xenodon rabdocephalus (Wied, 1824) $(\mathrm{n}=12)$, Lachesis muta $($ Linnaeus, 1766) $(\mathrm{n}=10)$ e Erythrolamprus almadensis (Wagler, 1824) $(\mathrm{n}=10)$. A composição de espécies encontrada representa uma combinação entre a fauna de Cerrado e Amazônica.

PALAVRAS-CHAVE. Squamata, Floresta Amazônica, savana, comunidade, ecótono.

The great biological diversity found in the Amazon region may be partly accounted by historical events that occurred during the Pleistocene, such as the formation of river systems, and climatic and geological changes which, combined, produced the present-day ecosystem heterogeneity (TuOMisto \& RuOKOLAINEN, 1997; Ron, 2000). Historical factors are directly related to the diversity and distribution of species, and the same occurs with snakes (Cadle \& Greene, 1993; Ávila-Pires, 1995). In the Brazilian "Cerrado" (savanna-like grassland), established reptilian groups have diversified in response to prevailing conditions, such as open formations with low structural habitat diversity and periodic natural burn-offs (CoLLI et al., 2002), resulting in high rates of endemism typical of this biome (SAWAYA et al., 2008).

Ecology and phylogeny may account for the structure of a snake community, and the morphological variation among species might be a response to ecological factors such as habitat use and diet (França et al., 2008). The unique history of each group that makes up a community imposes a series of limitations - morphological, physiological, and behavioral - that influence the ecological role of each lineage (CAdle \& Greene, 1993). Over the past few decades, an increasing number of studies of South American snake communities have become available, although data are still scarce for communities of Brazilian
Amazon (Martins \& Oliveira, 1998; Bernarde \& Abe, 2006; Santos-Costa et al. 2015), Pantanal (Strüssmann, 2000), Cerrado (CARValho \& Nogueira, 1998; SaWAYa et al., 2008), Atlantic Forest (Hartmann et al., 2009), and Pampa (Zanella \& Cechin, 2006).

Moreover, basic information about feeding ecology, reproductive biology, and habitat use of South American snakes have all been relatively well studied, providing the basis for the identification of certain patterns, such as the reproductive seasonality of species inhabiting temperate zones (Marques \& Puorto, 1998; Pizzato et al., 2007), and the lack of seasonality in tropical climates (SANTOSCosta et al., 2006; MASCHIO et al., 2007; PRUDENTE et al., 2007; Albarelli \& Santos-Costa, 2010; Bernarde \& ABE, 2010; MASChio et al. 2010, Siqueira et al. 2012).

The diversity of snakes in the Neotropical region is among the highest in the world. A total of 375 species have been recorded in Brazil (BÉRNILS \& COSTA, 2012), of which 149 can be found in the Amazon biome (Ávilla-PIRES et al., 2007), which is characterized not only by a high species diversity, but also by a considerable diversity of environments (Duellman, 1978). In contrast, the Cerrado is characterized by a high rate of endemism and 117 species have been described so far (SAWAYA et al., 2008).

A potentially interesting approach to understanding community structure is the analysis of the assemblages found 
in transition zones between biomes, known as ecotones. In order to fully understand the species composition of such areas, it is necessary to have reliable data not only on the ecotone itself, but also on the neighboring biomes. In a study of the snakes in a Caatinga (semi-arid region)Cerrado ecotone, a predominance of Cerrado species was observed, and it was estimated that the more complex the structure of the vegetation cover, the more species would be found in a given area (RochA \& Prudente, 2010). In a Cerrado-Amazon ecotone, by contrast, a predominance of Amazonian species was recorded (M. A. Carvalho, unpublished data).

The transition zone between Amazon and Cerrado biomes is characterized by areas of both rainforest and seasonal forest (IBGE, 2004a,b), which contribute to the formation of a relatively complex environment (PRIMACK \& RoDRIGUes, 2001), but with relatively species-poor vegetation compared to equivalent Amazonian habitats (IvANAUSKAS et al., 2004). The municipality of Querência, in the Brazilian state of Mato Grosso, was originally covered by transitional Amazon-Cerrado forest, which has now been altered drastically due to the advance of industrialized soybean farming. Due to the rapid conversion of forests into open areas, and the need for use of fauna, our objective is to identify the snake fauna that inhabits this environment transition, knowing whether there is a predominance of species of the Amazon or the Cerrado, and to provide information on species structure and ecology.

\section{MATERIAL AND METHODS}

Study area. We collect on the large Tanguro farm (12 $\left.54^{\prime} \mathrm{S} ; 52^{\circ} 22^{\prime} \mathrm{W}\right)$, located on the upper Xingu River (Fig. 1), in Querência Municipality, northeast of the Brazilian State of Mato Grosso. The municipality is located within the ample transition zone between the Amazonian and Cerrado biomes, although this locality belongs to the Legal Amazonia political division (IBGE, 2005). The climate is tropical, with a well-defined dry season between June and September, and a rainy season between December and March (IPAM, 2007). Mean annual rainfall is approximately $1900 \mathrm{~mm}$, and precipitation is less than $100 \mathrm{~mm}$ during the driest month and mean temperatures are above $18^{\circ} \mathrm{C}$ in the coldest month (PeEL et al., 2007). The farm covers a total area of 82,000 hectares, of which 38,000 ha have been deforested for agriculture, mainly soybean plantations.
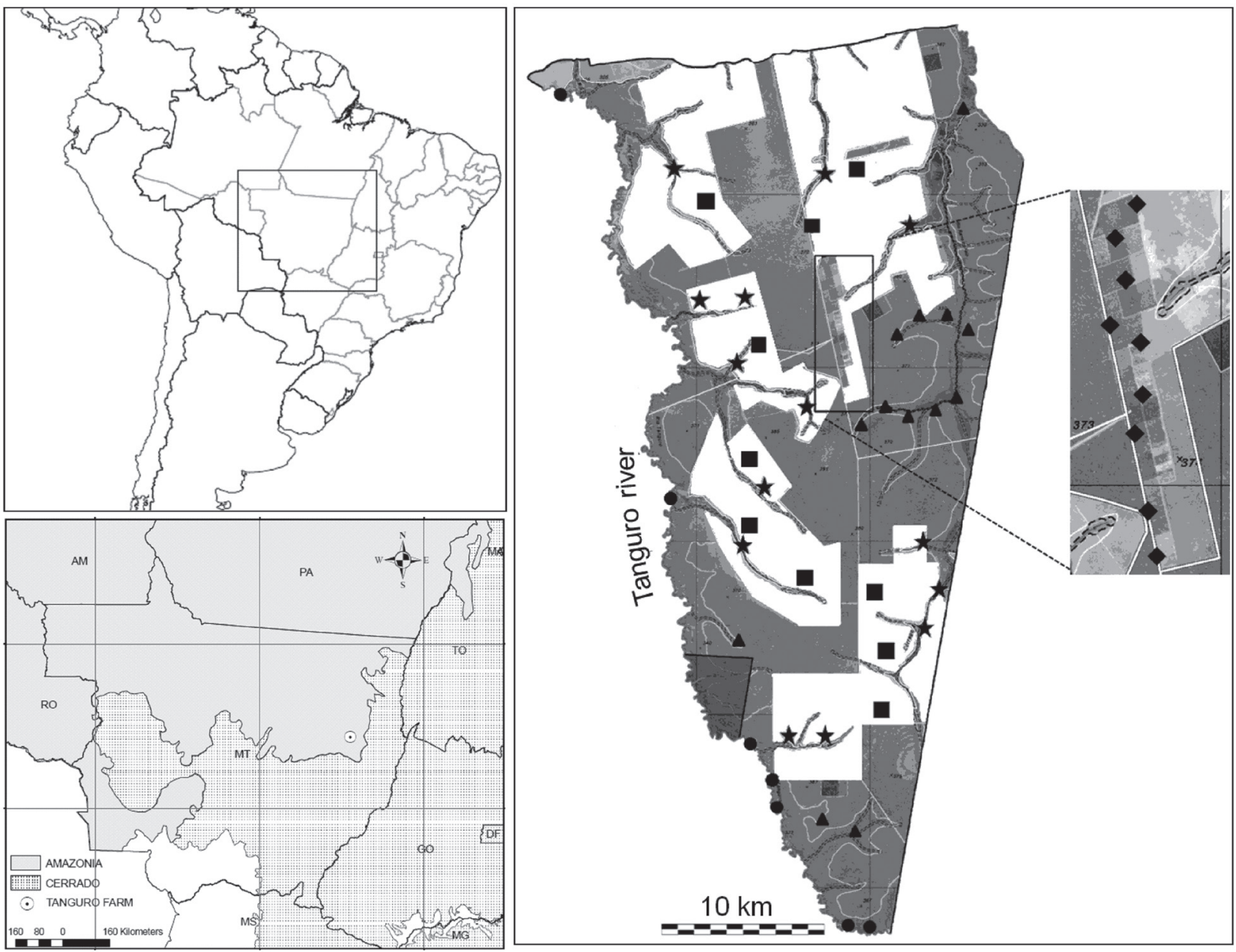

Fig. 1. Tanguro farm, Mato Grosso, Brazil (triangles, Preserved gallery forest (PGF); Stars, Highly anthropogenic gallery forest (HAG), adjacent to soybean plantations; Squares, Soybean plantation (SP), areas with no permanent vegetation; diamond, Hevea brasiliensis plantation (RP); circles, margin of the Tanguro River (MTR) (image modified from IPAM, 2007). 
The property also has an ample variety of gallery forests, adjacent to watercourses which are part of the Xingu drainage basin, such forests are under environmental protection (Federal law n⿳0.7771/1965).

Field data collection. Snakes were collected in six different habitat types, with the aim of sampling all environmental variation in study site. We did measurement of circumference at breast height and leaf litter depth just for the habitat characterization. We categorize habitats as: (1) PGF - Preserved gallery forest, with little impact from local agricultural activities, and located at least $800 \mathrm{~m}$ from deforested areas; mean tree circumference at breast height (CBH) $19.7 \mathrm{~cm}$, and mean leaf litter depth $4.1 \mathrm{~cm}$; (2) HAG - Highly anthropogenic gallery forest, adjacent to soybean plantations, trees with mean $\mathrm{CBH}$ of $18 \mathrm{~cm}$ and mean leaf litter depth of $1.7 \mathrm{~cm}$. These areas are highly impacted and away from the edge of the water body to the edge of the forest does not exceed $20 \mathrm{~m}$, in some areas we noted the presence of cattle; (3) SP - Soybean plantation, with no permanent vegetation. In this area seasonal crops of soybeans and other grains are done. In some periods of the year the soil is completely exposed; (4) RP - Rubber (Hevea brasiliensis) plantation, evenly-spaced trees with mean CBH of $64.05 \mathrm{~cm}$, floor covered only with dead leaves and twigs from the rubber trees, and a mean litter depth of $0.97 \mathrm{~cm}$. The leaf litter in this area is periodically removed; (5) MTR - Margin of the Tanguro River, conditions similar to those of the PGF, with a mean $\mathrm{CBH}$ of $16.21 \mathrm{~cm}$ and leaf litter of $1.62 \mathrm{~cm}$. This gallery forest is bordered by a wide river, with a minimum width of five meters, while the PGF areas have small streams; (6) EFZ - Experimental fire zone, an area used by the Instituto de Pesquisa Ambiental da Amazônia (IPAM) for research into the savannization of local forests, these areas are submitted to experimental fires annually.

We collect specimens in six expeditions between 2006 and 2010, a total of 190 days spent collecting data. We divided such activities into two stages. In the first stage, we collected in four distinct periods, each one of thirty days in 2006 (February and October), 2007 (February), and 2008 (July). In the second stage, we collects in two distinct periods, each one of forty-five days in 2009 (November-December) and 2010 (March-April). We used three different methods to capture snakes: (a) VES - Visual Encounter Survey: a team formed by three or four collectors walked slowly on existing trails in each of the habitats (adapted from MarTins \& OliveIRA, 1998). Each VES lasted three hours, conducted during all six expeditions. During each VES, we check the largest possible numbers of microhabitats, including leaf litter, shrubs, fallen trees, permanent and temporary bodies of water, and so on; (b) DFP - Drift fences with pitfall traps: we used these traps during the first stage in three habitats - PGF (two sample points), HAG (two points), and EFZ (one point). The traps consisted of five $60 \mathrm{~L}$ buckets set in a line at 10 $\mathrm{m}$ intervals. We buried the buckets to the on the ground to the brim. Then we connected the buckets by a one meter height drift fence. We installed three sets of traps in each habitat, every set was formed by three lines of buckets, at least $200 \mathrm{~m}$ distant from each other (modified from Cechin \& Martins, 2000); (c) NSS - Non-systematic sampling: non-standardized procedure that consists of the collection of specimens (dead or alive) encountered by members of the research team or local residents during their everyday activities, i.e. not during VES or DFP procedures. Specimens were collected in this way at the sampling points and adjacent areas, in the base camp, fields, and on access roads (adapted from MARTINS \& OliveIRA, 1998).

Data analysis. For each individual observed or collected, recorded the following data: date and time of collection, habitat and microhabitat, location within the study site. The preserved specimens were deposited in the herpetological collection of the "Museu Paraense Emílio Goeldi” (MPEG) in Belém, Pará, Brazil. In order to estimate the total number of species occurring within the study site, the data from the visual encounter survey was weighted by the number of hours spent searching and the number of collectors (collector-hours). We apply the non-parametric Jackknife 1 species richness estimator to these data using the Estimates program (COLWELL, 2012), version 8.2.0.

Species composition was compared with data from snake assemblages of different biomes: Amazon Forest (Martins \& Oliveira, 1998; Bernarde \& Abe, 2006; MASCHIO et al., 2009 and M. A. Carvalho, unpublished data); Cerrado (CARValHo \& Nogueira, 1998; StrüssmanN, 2000; SAWAYA et al., 2008); Brazilian Atlantic Forest (O. A. V. Marques, unpublished data; S. A. A. Morato, unpublished data). We compare the different sites using a Principle Coordinates Analysis (PCoA) (MANLY, 1994), based on the presence/absence of 283 species at the ten sites surveyed. Analyses were performed using the program Past and the similarity Jaccard index (HAMmer et al., 2001).

Species were grouped in ecological guilds according to their ecological attributes: substrate (terrestrial, aquatic, semi-aquatic, arboreal, semi-arboreal, fossorial), activity period (diurnal, nocturnal, crepuscular), and prey type, based on information available in the literature (see Table I). We define guilds using a multivariate grouping analysis (cluster) of the data on diet, substrate use, and activity cycle collected during this study and those available in the indexed literature. This analysis was based on the similarity index of Sorensen and a Weighted Pair Group Method with Arithmetic Mean or WPGMA (SNEATH \& SOKAL, 1973), performed in the MVSP 3.1 program (KovaCH, 1999).

\section{RESULTS}

We collected 194 specimens (only nine other individuals were observed) during all expeditions. These specimens represented 34 species, 26 genera, and eight families. The first-order Jackknife estimate of species richness indicated a potential richness of 38 species, suggesting that few species have yet to be recorded in the study area. The most abundant species (Tab. I) were 


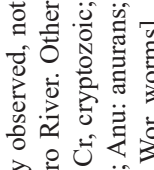

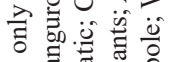

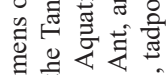

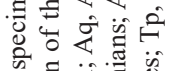

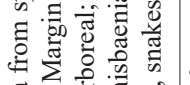

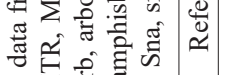

吸安手

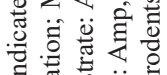

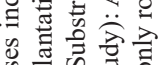

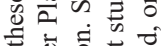

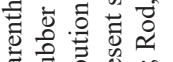

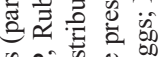

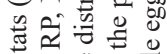

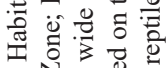

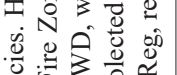

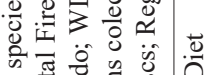

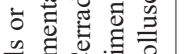

글

क्षे की की

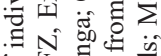

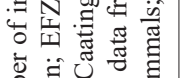

है.

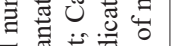

递 $\frac{\pi}{a}$.

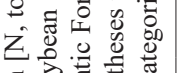

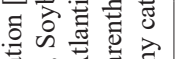

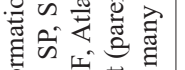

急苟出.

욜

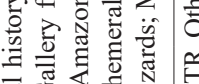

可 可文

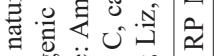

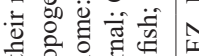

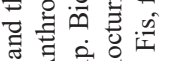

完目各语

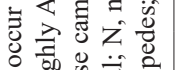

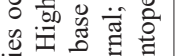

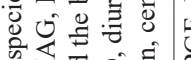

के ची चี

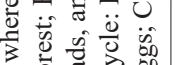

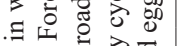

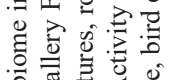

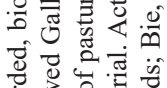

范

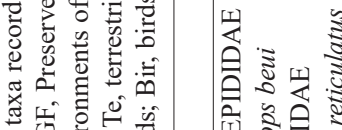

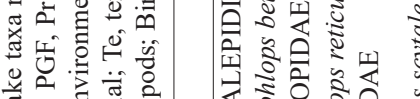

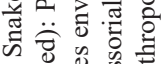

की

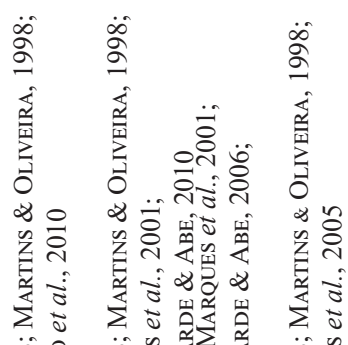

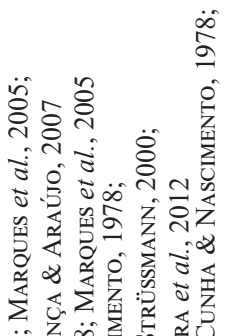

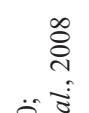

享芯苍苍

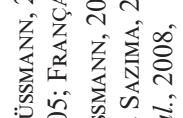

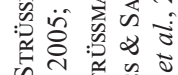

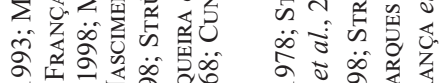

งิ

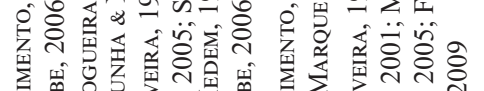

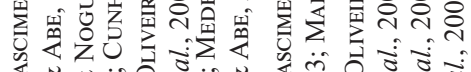

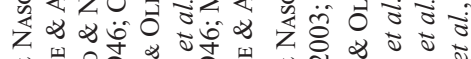

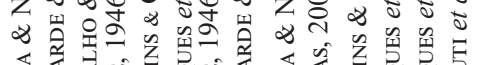

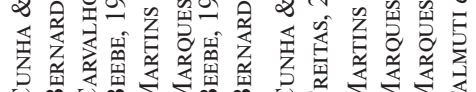

言

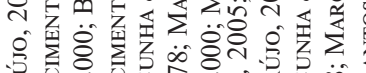

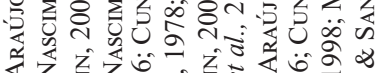

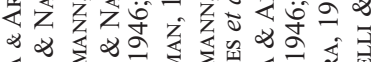

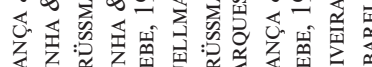

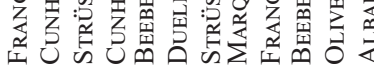




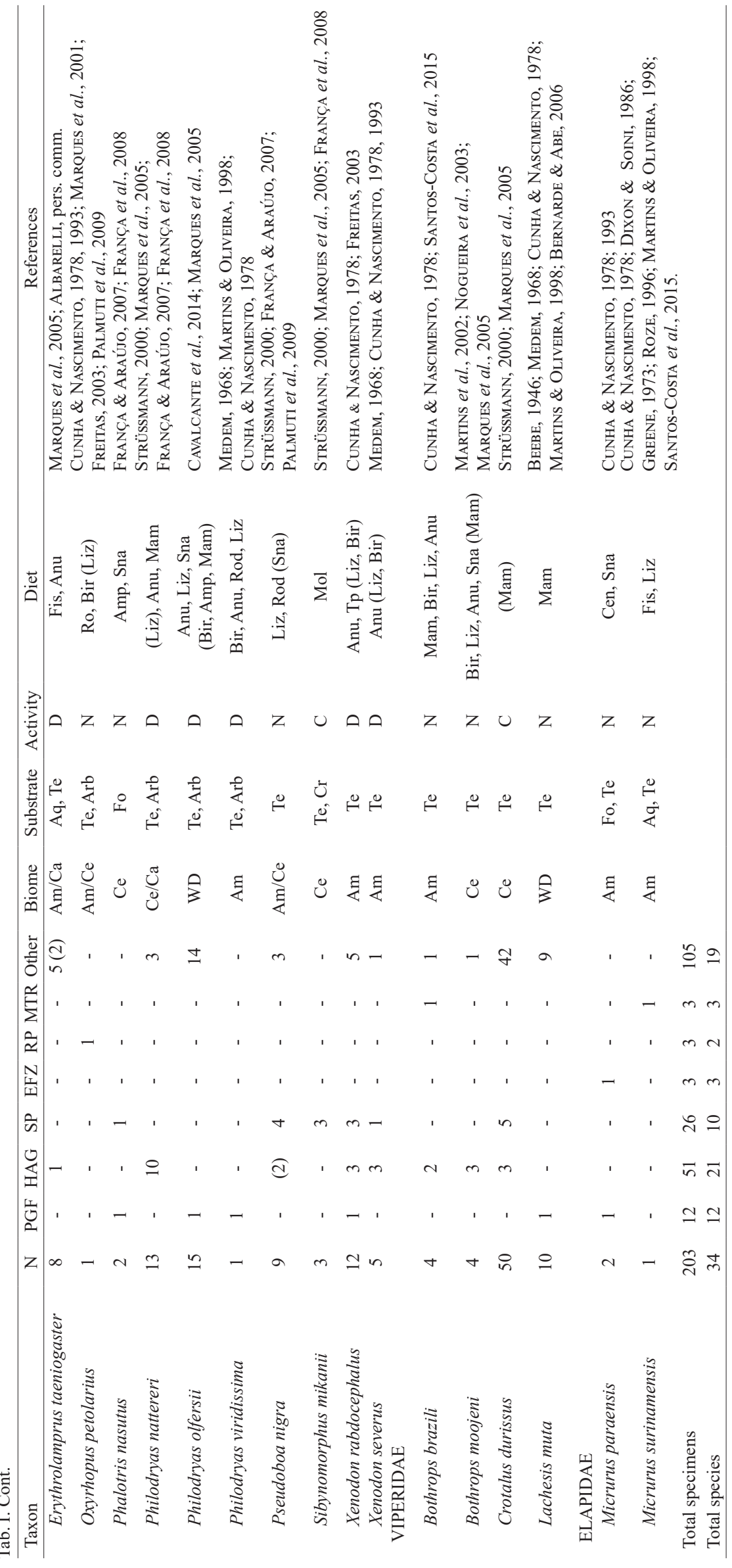


Crotalus durissus $(\mathrm{n}=50)$, Philodryas olfersii $(\mathrm{n}=15)$, Philodryas nattereri $(\mathrm{n}=13)$, Xenodon rabdocephalus $(\mathrm{n}=$ 12), Lachesis muta ( $\mathrm{n}=10)$, and Erythrolamprus almadensis $(\mathrm{n}=10)$. However, most of the other species were relatively rare, and eight were recorded only once during the study. We classified nine species with predominant occurrence in open areas (Cerrado and Caatinga) and 11 as forestry species (Amazonia), 23\% of the species occur both open (Cerrado and Caatinga) and forest (Amazonia and Atlantic Forest) areas, about $18 \%$ of the species is widely distributed (Tab. I).

We recorded twelve species in the preserved gallery forest, of which three (Philodryas viridissima, Imantodes cenchoa, and Chironius exoletus) were exclusive to this habitat (Tab. I). In contrast, 21 species were collected in the highly anthropogenic gallery forest, including eight exclusive taxa. Of the ten species recorded in the soybean plantations, only one (Sibynomorphus mikanii) was exclusive. Three species were recorded in both the experimental fire zone and the margin of Tanguro River, and only the latter had an exclusive taxon (Micrurus surinamensis). In the rubber plantation, only two taxa (Oxyrhopus petolarius and Liotyphlops beui) were recorded. In non-systematic samplings, 19 species were collected (Tab. I).
Comparing the Tanguro community with other locations, the first two axes of the main coordinate analysis (Fig. 2) correspond to $49.43 \%$ of the variance of the data (axis 1: eigenvalue $=0.81$, variance $=25.5 \%$; axis 2 : eigenvalue $=0.76$, variance $=23.8 \%$ ). The arrangement produced by the PCO in the two-dimensional space didn't identify any overlapping between the different communities and defined three distinct groups, representing the three biomes surveyed (Amazon, Cerrado, and Atlantic Forest). The Tanguro community occupies a clearly intermediate area between the Amazonian and Cerrado groups (Fig. 2).

The dendrogram generated by cluster analysis differentiated four main groups, based on their ecological parameters (literature data), i.e. diet, substrate use, and activity cycle (Fig. 3). Group 1 was comprised of nocturnal, semi-aquatic species that feed primarily on fish and amphibians. Two groups are comprised of terrestrial and/or semi-arboreal species, one with species that feed primarily on anurans (group 2) and the other with dietary generalists (group 3). Group 4 is comprised of nocturnal, fossorial and/or cryptozoic snakes.

Regarding information on the natural history of snakes recorded in Tanguro farm, most of the snakes collected were terrestrial $(32.3 \%, \mathrm{n}=11)$ or semi-arboreal $(29.5 \%, \mathrm{n}=10)$. The remaining species were all either

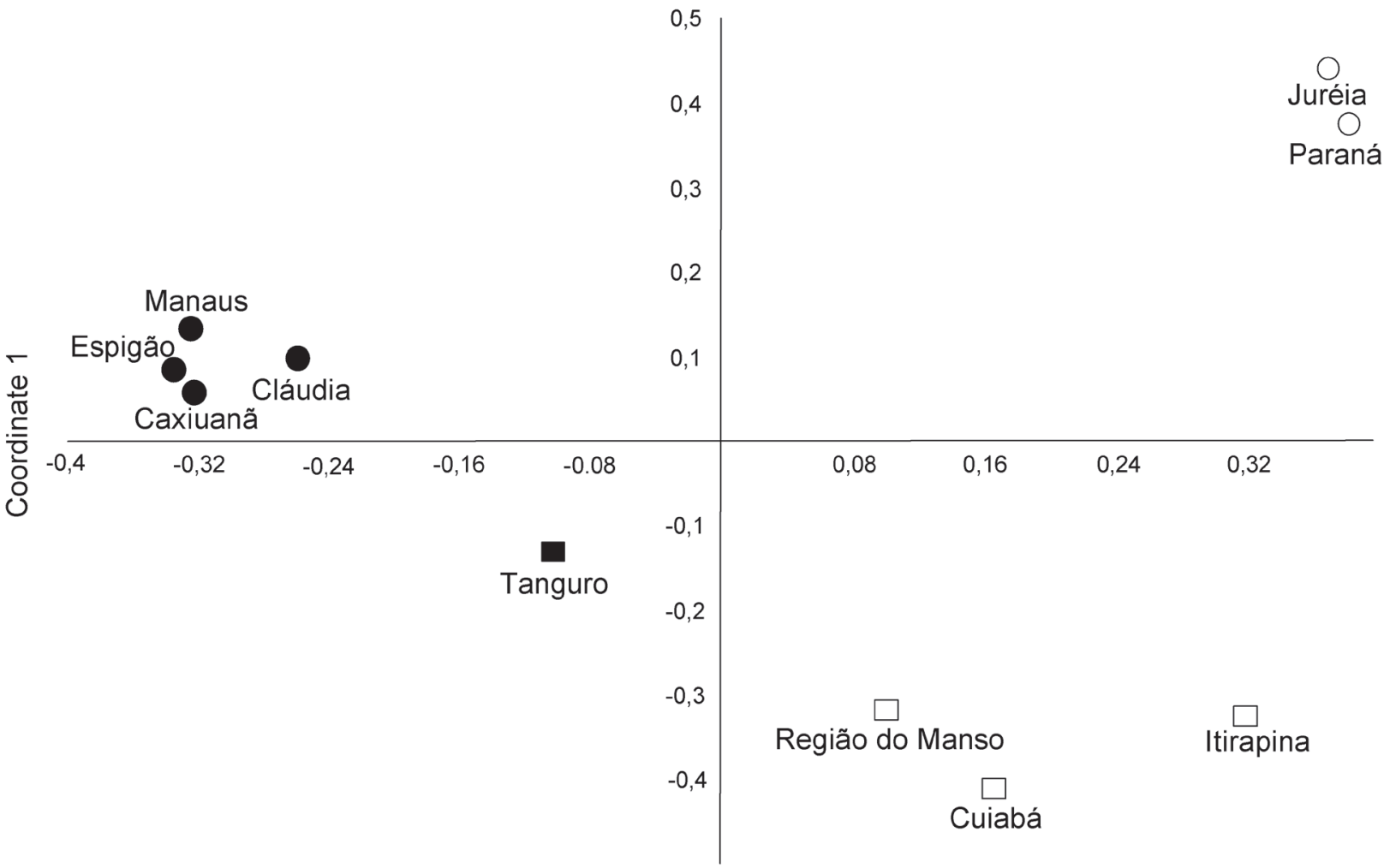

Coordinate 2

Fig. 2. Diagram derived from the Principle Coordinates Analysis (PCO) of the species composition of the snake communities (presence/absence of 171 species) of ten localities representing the Amazonia (closed circles), Cerrado (open squares), and Atlantic Forest (open circles) biomes. Amazonia: Manaus (Martins \& Oliveira, 1998); Caxiuanã (Maschio et al., 2009); Espigão do Oeste (Bernarde \& Abe, 2006); Claudia, MT (M. A. Carvalho, unpublished data). Cerrado: região do Manso (Strüssmann, 2000); Cuiabá (CARvalho \& Nogueira, 1998); Itirapina (SAwaYa et al, 2008). Atlantic Forest: Juréia (MArques, 1998); Paraná (S. A. A. Morato, unpublished data). 


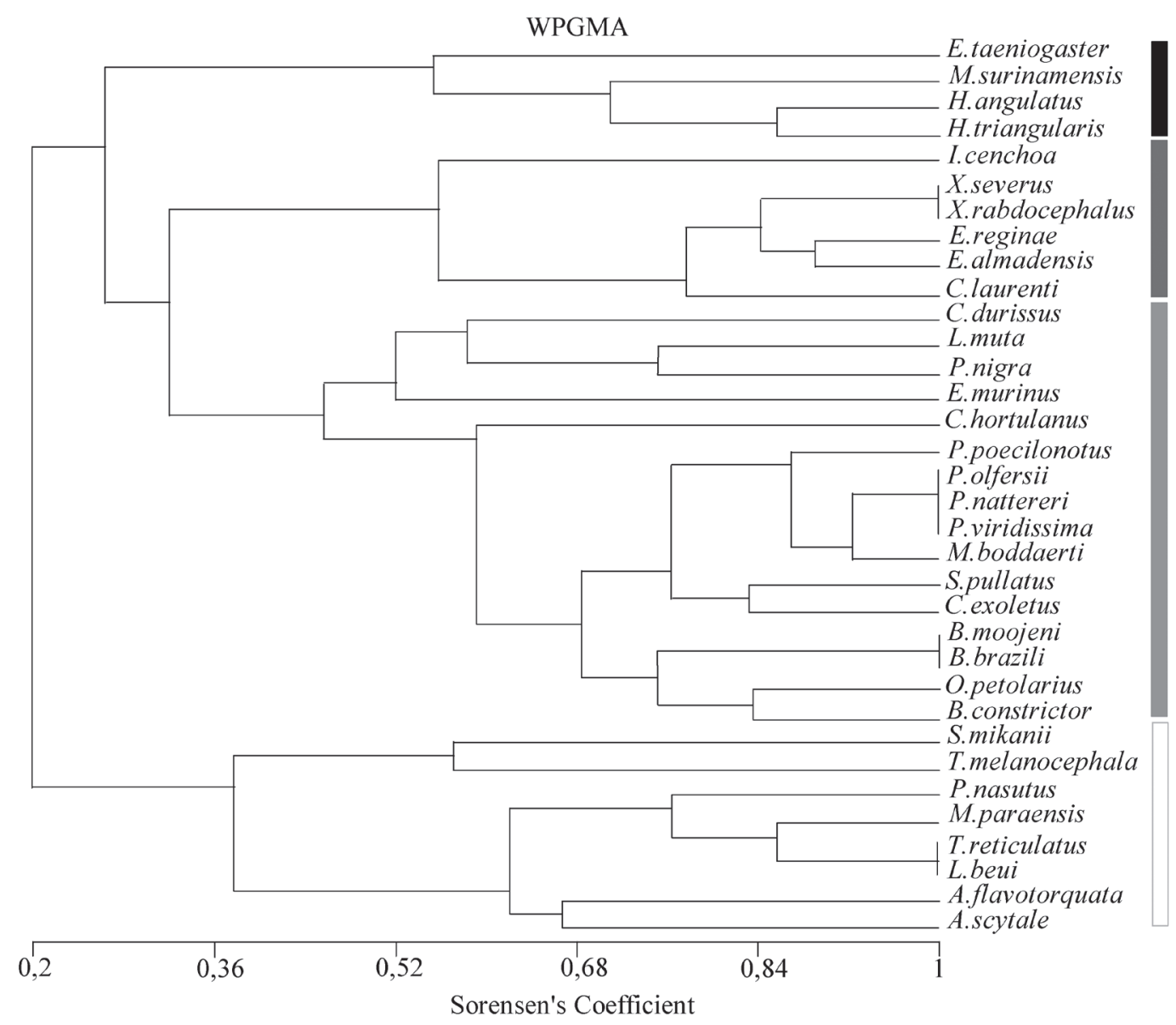

Fig. 3. Dendrogram generated by the WPGMA cluster analysis of the snake species collected at Tanguro, Mato Grosso, Brazil. Different colors represent the ecological guilds, based on diet, substrate use, and activity cycle: black (nocturnal, semi-aquatic species that feed primarily on fish and amphibians); dark gray (terrestrial and/or semi-arboreal species, feed primarily on anurans); light gray (terrestrial and/or semi-arboreal species, generalist diet); white (nocturnal, fossorial and/or cryptozoic).

fossorial $(23.5 \%, \mathrm{n}=8)$ or semi-aquatic $(14.7 \%, \mathrm{n}=5)(\mathrm{Tab}$. I). Almost half of the species, $44.1 \%(\mathrm{n}=15)$, was diurnal, $38.3 \%(\mathrm{n}=13)$ were nocturnal, and $17.6 \%(\mathrm{n}=6)$ were crepuscular species. Lizards were the prey item observed in the largest number of species $(61.7 \%, \mathrm{n}=21)$, followed by amphibians, with $47.1 \%, n=16$ (Tab. I). Small-bodied mammals were the next most common dietary item, found in $44.1 \%$ of the species $(n=15)$. This type of prey was the main dietary item for nine of these species. Birds were ingested by 14 species $(41.1 \%)$, followed by fish $(17.6 \%$, $\mathrm{n}=6)$, snakes $(17.6 \%, \mathrm{n}=6)$, amphisbaenians $(14.7 \%, \mathrm{n}$ $=5)$, and invertebrates $(14.7 \%, \mathrm{n}=5)$. Most species were generalists, consuming two or more different types of prey.

\section{DISCUSSION}

The snake community found here exhibit species from Amazon and Cerrado biomes. The presence of a transitional areas of forest and open habitats generate a high heterogeneous environment, allowing the presence of species with different habitats requirements. Habitat generalist species as Boa constrictor, Corallus hortulanus,
Helicops angulatus, Spilotes pullatus, Philodryas olfersii, and Erythrolamprus reginae, are found in many biome types, including the Caatinga scrublands of the Brazilian Northeast (COLli et al., 2002; RoDRIGUES, 2003; MARQUES et al., 2005) and peripheral areas of the Cerrado (Couto et al., 2007). In contrast, Typhlops reticulatus, Bothrops brazili, Hydrops triangularis, and Pseustes poecilonotus are found predominantly in the Amazon basin (CUNHA \& Nascimento, 1993; Martins \& Oliveira, 1998; Prudente \& Santos-Costa, 2005; Maschio et al., 2009), while Phalotris nasutus, Liotyphlops beui, and Apostolepis flavotorquata are found in the Cerrado (FRANÇA et al., 2008). Overall, the species composition of the local snake community further reinforces the ecologically transitional nature of the study area as an ecotone of the Amazon and Cerrado biomes.

The expansion of soybean farming may be a factor which favors the establishment of Crotalus durissus in the region (most abundant species). The high abundance is probably related to the adaptations of this species to open habitats, which probably also underpin its capacity to occupy disturbed habitats (TozeTti \& Martins, 2008). 
The increasing availability of resources such as grains may underpin an increase in small mammal prey, such as the rodents. High density of small mammals, which are the main preys to $C$. durissus, were already detected on the study area, specially surrounding the base camp, inside and around the soybean plantations (Mendes-Oliveira et al., 2012).

The larger number of species found in the highly anthropogenic gallery forest compared to the preserved gallery forest is a pattern which has also been reported by PONTES et al. (2009), who compared forest areas with banana plantations. Intense human activities, typical of agricultural areas, tend to result in a reduction of snake abundance, diversity, and species richness (ZUG et al., 2001). The disturbance intensity and frequency may determine the abundance and species richness of an assemblage (ABUGOv, 1982; Huston, 1994; TowsEND et al., 1997). These three elements might explain the differences in richness and abundance found in different habitats in the study site where disturbances are from different intensity, such as experimental fire zones, rubber plantations, and the margins of the Tanguro river. Our results corroborate the theory of intermediate disturbance where complex habitats, with intermediate levels of disturbance tend to have higher species richness (e.g. GrIME, 1973; HoRN, 1975; ConNel, 1978; ToKeshI, 1999). This pattern was also found to amphibian communities in the same locality of this study (BITAR et al., 2014). On the other hand, the local composition changes, adding opportunistic species to the local pool and may cause local extinctions of species susceptible to environmental changes, leading what we know as homogenization of fauna (SHMIDA \& WILSON, 1985; Olden et al., 2004).

The food availability resource has been identified as crucial in structuring snake communities (VITT \& Vangilder, 1983; Gibbons \& Semlitsch, 1987; Cadle \& GREENE, 1993). Moreover, temperature and humidity (among other environmental parameters) are considered important factors in diversity and distribution not only of snakes but also of their prey (GibBons \& SEMLitsch, 1987; Lillywhite, 1987; Di-Bernardo et al., 2007). Most recorded species were generalist species. This group appears to be the most favored by the conditions found within the study area, particularly the availability of a wide range of prey, allowing for the adoption of an opportunistic foraging strategy (CADLE \& GREENE, 1993). This strategy is reflected on the diversity of prey items recorded in this group - lizards, anurans, rodents, and birds. This group is characterized by the large number of species that feed on mammals, a fact that is probably linked to the increase in the local abundance of certain species of small mammals, especially rodents, in anthropogenic habitats (SCHEIBLER \& CHRISTOFF, 2007).

We have identified a small number of guilds compared to the results of surveys conducted at other Amazonian sites, due primarily to the reduced number of arboreal species (MARTINS \& OLIVEIRA, 1998), presumably reflecting the degree of specialization of these species and their vulnerability to habitat loss (LILLYWHITE \& HENDERSON, 1993). The marked predominance of one ecological group (snakes with generalist habitat preferences) is an additional characteristic that distinguished the community analyzed in this study from all others documented in the Amazon basin. This is probably related to both the ecotonal nature of the region and the loss of microhabitats resulting from agricultural activities.

Finally, although the study site is located in a heavily disturbed area and with strong interference of agriculture, site environmental heterogeneity may be maintaining a relative richness of snake species. The permanence of forest remnants eventually maintains the species which are typical of this environment (mostly, Amazon species); on the other hand, the advance of the agricultural frontier favors the establishment of open habitat species (predominantly, species from the Cerrado). And the environmental heterogeneity may also favor those species that have phenotypic plasticity (generalist species habitat, with a greater dispersal capacity). Thus, the disturbances have not turned the study site (when we analyzed the total area) into a homogeneous area, which is associated to an overt loss of species (OLDEN et al., 2004). However, we can observe losses when analyzing the sites separately, as observed for amphibians (BITAR et al., 2012).

Acknowledgements. We are grateful to the Instituto de Pesquisa Ambiental da Amazônia (IPAM) for their logistic support in the field. We thank Oswaldo Portela, Adriano Portela, Adilson, Joélson Serrão, Aderlan Pedroso, Darlisson, Raimundo Nonato and Fernanda Magalhães the field assistance. Dr. Ana Prudente and Dr. Darlan Feitosa (Museu Paraense Emílio Goeldi) kindly identified the species. Gleomar Maschio by discussion and suggestions. This paper was supported by $\mathrm{CNPq}$ and CAPES by granting scholarship, PPG7/FINEP (financial support) and the UFPA/MPEG Pos-Graduate Program in Zoology (infrastructure). IBAMA for permission to collection specimens through the special license number 1875-1.

\section{REFERENCES}

AbugOv, R. 1982. Species diversity and phasing of disturbance. Ecology 63:289-293.

Albarelli, L. P. P. \& Santos-Costa, M. C. 2010. Feeding ecology of Liophis reginae semilineatus (Serpentes: Colubridae: Xenodontinae) in Eastern Amazon, Brazil. Zoologia 27(1):87-91.

Ávila-PIRes, T. C. S. 1995. Lizards of Brazilian Amazonia (Reptilia: Squamata). Zoologische Verhandelingen 299:1-706.

Ávila-Pires, T. C. S.; Hoogmoed, M. S. \& VitT, L. 2007. Herpetofauna da Amazônia. In: Nascimento, L. B. \& Oliveira, M. E. eds. Herpetologia no Brasil II. São Paulo, Sociedade Brasileira de Herpetologia, p. 13-43.

BeEbe, W. 1946. Field notes on the snakes of Kartabo, British Guiana, and Caripito, Venezuela. Zoologica 31:11-52.

Bernarde, P. S. \& ABE, A. S. 2006. Snake communities at Espigão do Oeste, Rondônia, Southwestern Amazon, Brazil. South American Journal of Herpetology 1:102-113.

2010. Hábitos alimentares de serpentes em Espigão do Oeste, Rondônia, Brasil. Biota Neotropica 10(1):167-173.

BÉRNILS, R. S. \& CosTA, H. C. orgs. 2012. Brazilian reptiles - List of species. Version 2012.2. Available at $<\mathrm{http}: / / \mathrm{www}$.sbherpetologia. org.br/>. Accessed June 2014.

Bitar, Y. O. C; Pinheiro, L. C.; Abe, P. S. \& Santos-Costa, M. C. 2012. Species composition and reproductive modes of anurans from a transitional Amazonian forest, Brazil. Zoologia 29(1):19-26. 
Bitar, Y. O. C; Juen, L.; Pinheiro, L. C. \& Santos-Costa, M. C. 2014 Anuran Beta Diversity in a Mosaic Anthropogenic Landscape in Transitional Amazon. Journal of Herpetology 49(1):75-82.

CAdLe, J. E. \& Greene, H. W. 1993. Phylogenetic patterns, biogeography, and the ecological structure of Neotropical snake assemblages. In: RICKLEFS, R. E. \& SCHLUTER, D. eds. Species diversity in ecological communities: historical and geographical perspectives. Chicago, University of Chicago Press, p. 281-293.

Carvalho, M. A. \& Nogueira, F. 1998. Serpentes da área urbana de Cuiabá Mato Grosso: aspectos ecológicos e acidentes ofídicos associados. Cadernos de Saúde Pública Rio de Janeiro 14:753-763.

Cavalcanti, L. B. Q.; Costa, T. B.; Colli, G. R.; Costa, G. C.; França, F. G. R.; Mesquita, D. O. \& Palmeira, C. K. S. 2014. Herpetofauna of protected areas in the Caatinga II: Serra da Capivara National Park, Piauí, Brazil. Check List 10(1):18-27.

Cechin, S. Z. \& Martins, M. 2000. Eficiência de armadilhas de queda (pitfall traps) em amostragem de anfíbios e répteis no Brasil. Revista Brasileira de Zoologia 17:729-740.

Colli, G. R.; Bastos, R. B. \& AraúJo, R. B. 2002. The character and dynamics of the Cerrado herpetofauna, In: OliveIRA, P. S. \& MARQuis, R. J. eds. The Cerrados of Brazil, Ecology and natural history of a Neotropical savanna. New York, Columbia University Press, p. 233-241.

Connel, J. H. 1978. Diversity in tropical rainforest and coral reefs. Science 199:1302 -1310.

Couto, L. F.; Terribile, L. C. \& Diniz-Filho, J. A. F. 2007. Padrões espaciais e conservação da diversidade de serpentes do bioma do Cerrado. Acta Scientiarum, Biological Sciences 29:65-73.

Colwell, R. K. 2012. EstimateS: Statistical estimation of species richness and shared species from samples. Version 9. User's Guide and application published at: http://purl.oclc.org/estimates.

CosTA, G. C. 2010. Liotyphlops beui. The IUCN Red List of Threatened Species. Version 2014.3. Avaliable at: <www.iucnredlist.org>. Accessed on February 2015.

Cunha, O. R. \& Nascimento, F. P. 1978. Ofídios da Amazônia X - As cobras da região leste do Pará. Publicações Avulsas do Museu Paraense Emílio Goeldi 31:1-218.

Cunha, O. R. \& Nascimento, F. P. 1993. Ofídios da Amazônia. As cobras da região Leste do Pará. Boletim do Museu Paraense Emílio Goeldi, Série Zoologia 9:1-191.

Dixon, J. R. \& SornI, P. 1986. The Reptiles of the Upper Amazon Basin, Iquitos Region, Peru. Milwaukee Public Museum, Milwaukee. 154p.

Di-bernardo, M.; Borges-Martins, M.; Oliveira, R. B. \& Pontes, G. M. P. 2007. Taxocenoses de serpentes de regiões temperadas do Brasil. In: Nascimento, L. B. \& Oliveira, M. E. eds. Herpetologia no Brasil II. Belo Horizonte, Sociedade Brasileira de Herpetologia, p. $222-263$

DuELLMAN, W. E. 1978. The biology of an equatorial herpetofauna in Amazonian Ecuador. Museum of Natural History of the University of Kansas, Miscellaneous Publications 65:1-352.

França, F. G. R. \& AraúJo, A. F. B. 2007. Are there co-occurrence patterns that structure snake communities in Central Brazil? Brazilian Journal of Biology 67(1):33-40.

França, F. G. R.; Mesquita, D. N.; Nogueira, C. C. \& Araújo, F. B. A. 2008. Phylogeny and Ecology determine morphological structure in a snake assemblage in the Central Brazilian Cerrado. Copeia 2008:23-38.

Freitas, M.A. 2003. Serpentes Brasileiras. Lauro de Freitas, Publisher. $160 \mathrm{p}$.

Gibbons, J. W. \& Semlitsch, R. D. 1987. Activity patterns. In: Seigel, R. A.; Collins, J. T. \& NovaK, S. S. eds. Snakes: ecology and evolutionary biology. New York, McGraw-Hill, p.184-209.

GreEne, H. W. 1973. Defensive tail display in snakes and amphisbaenians. Journal of Herpetology 7:43-61.

Grime, J. P. 1973. Control of species density in herbaceous vegetation. Journal of Environmental Management 1:151-167.

Hammer, Ø.; HarPer, D. A. T. \& RyAn, P. D. 2001. PAST: Paleontological statistics software package for education and data analysis. Paleontologia Electronica 4(1): 1-9. Avaliable at $<$ http://palaeoelectronica.org/2001 1/past/issue1 01.htm>.
Hartmann, P. A.; Hartmann, M. T. \& Martins, M. 2009. Ecologia e história natural de uma taxocenose de serpentes no Núcleo Santa Virgínia do Parque Estadual da Serra do Mar, no sudeste do Brasil. Biota Neotropica 9:1-12.

Horn, H. 1975. Markovian properties' of forest succession. In: Cody, M. \& Diamond, J. eds. Ecology and Evolution of Communities. Cambridge, Harvard University Press, p. 196-211.

Huston, M. A. 1994. Biological diversity: the coexistence of species on changing landscapes. Cambridge, Cambridge University Press. $681 \mathrm{p}$.

IBGE - Instituto Brasileiro de Geografia e Estatística. 2004a. Mapa de Biomas do Brasil. Escala 1: 5.000.000. Avaliable at $<$ www.ibge. gov.br $>$. Accessed on November, 2014.

IBGE - Instituto Brasileiro de Geografia e Estatística. 2004b. Mapa de Vegetação do Brasil. Escala 1: 5.000.000. Avaliable at $<$ www.ibge.gov.br $>$. Accessed on November, 2014.

IBGE - Instituto Brasileiro de Geografia e Estatística. 2005. Mapa de biomas e mapa de vegetação do Brasil. Avaliable at $<$ www. ibge.gov.br>. Accessed on November, 2014.

IPAM - Instituto de PesQuisa Ambiental da Amazônia. 2007. Avaliable at www.ipam.org.br. Accessed on February, 2015.

IvANAUSKas, N. M.; Monteiro, R. \& Rodrigues, R. R. 2004. Estrutura de um trecho de floresta Amazônica na bacia do alto rio Xingu. Acta Amazonica 34:281-305.

Kovach, W. L. 1999. MVSP - A multi-Variate statistical package for windows, ver. 3.1. Penthraeth, Kovach computing Services.

Lillywhite, H. B. 1987. Temperature, energetics and physiological ecology. In: Seigel, R. A.; Collins, J. T. \& NovaK, S. S. eds. Snakes: Ecology and Evolutionary Biology. New York, McGraw-Hill, p.422-477.

Lillywhite, H. B. \& Henderson, R. W. 1993. Behavioral and functional ecology of arboreal snakes. In: SeIGEL, R. A. \& Collins, J. T. eds. Snakes: Ecology and Behavior. New York, MacMillan Publication Community, p. 1-48.

Manly, B. F. J. 1994. Multivariate Statistical Methods. A primer. London, Chapman and Hall. 215p.

Marques, O. A. V.; Eterovic, A. \& Sazima, I. 2001. Serpentes da Mata Atlântica: Guia Ilustrado para Serra do Mar. Ribeirão Preto, Holos. 184p.

Marques, O. A. V. \& Sazima, I. 2004. História natural dos répteis da Estação Ecológica Juréia-Itatins. In: MARques, O. A. V. \& DulebA, W. eds. Estação Ecológica Juréia-Itatins. Ambiente físico, flora e fauna. Ribeirão Preto, Holos, p. 212-236.

Marques, O. A. V.; Eterovic, A.; Strüssmann, C. \& Sazima, I. 2005. Serpentes do Pantanal - Guia ilustrado. Ribeirão Preto, Editora Holos. 179p.

Marques, O. A. V. \& Puorto, G. 1998. Feeding, reproduction and growth in the crowned snake Tantilla melanocephala (Colubridae), from southeastern Brazil. Amphibia-Reptilia 19:311-318.

Martins, M. \& Oliveira, M.E. 1998. Natural history of snakes in forests of the Manaus Region, Central Amazonia, Brazil. Herpetological Natural History 6:78-150

Martins, M. R. C.; Marques, O. A. V. \& SaZima, I. 2002. Ecological and phylogenetic correlates of feeding habits in neotropical pitvipers of the genus Bothrops. In: Schuett, G. W.; HögGren, M. \& GREENE, H. W. eds. Biology of the Vipers. Indiana, Biological Sciences Press (Cooper Publishing Group), p. 307-328.

Maschio, G. F.; Prudente, A. L. C; Lima, A. C. \& Feitosa, D. T. 2007. Reproductive Biology of Anilius scytale (Linnaeus 1758) (Serpentes, Aniliidae) from Eastern Amazonia, Brazil. South American Journal of Herpetology 2:179-183.

Maschio, G. F.; Santos-Costa, M. C. \& Prudente, A. L. C. 2009. Comunidades de Serpentes da região de Caxiuanã com avaliação da eficiência dos métodos de captura. In: LISBOA, P. ed. Caxiuanã: Desafios para a conservação de uma Floresta Nacional na Amazônia. Belém, Museu Paraense Emílio Goeldi, p. 589-603.

Maschio, G. F.; Prudente, A. L. C.; Rodrigues, S. R. \& Hoogmoed, M. S. 2010. Foods habitat of Anilius scytale (Serpentes: Aniliidae) in the Brazilian Amazonia. Zoologia 27:184-190.

Medem, F. 1968. El desarrolo de la herpetologia en Colombia. Revista de la Academia Colombiana de Ciencias Exactas, Físicas y Naturales 13:149-200. 
Mendes-Oliveira, A. C.; Santos, P. G. P.; Carvalho-Júnior, O.; Montag, L. F. A.; Lima, R. C.; Maria, S. L. S. \& Rossi, R. V. 2012. Edge effects and the impact of wildfires on populations of small non-volant mammals in the forest-savanna transition zone in Southern Amazonia. Biota Neotropica 12(3):57-63.

Nogueira, C.; Sawaya, R. J. \& Martins, M. 2003. Ecology of the Pitviper, Bothrops moojeni, in the Brazilian Cerrado. Journal of Herpetology 37:653-659.

Olden, J. D.; Poff, N. L.; Douglas, M. B.; Douglas, M. E. \& Fausch, K. D. 2004. Ecological and evolutionary consequences of biotic homogenization. Trends in Ecology \& Evolution 19:18-24.

Palmuti, C. F. S.; Cassimiro, J. \& Bertoluci, J. 2009. Food habits of snakes from the RPPN Feliciano Miguel Abdala, an Atlantic Forest fragment of southeastern Brazil. Biota Neotropica 9(1):263-269.

Peel, M. C.; Finlayson, B. L. \& McMahon, T. A. 2007. Updated world map of the Köppen-Geiger climate classification. Hydrology and Earth System Sciences 11:1633-1644.

Pizzatto, L.; Almeida-Santos, S. M. \& Marques, O. A. V. 2007. Biologia reprodutiva de serpentes Brasileiras, In: Nascimento, L. B. \& Oliveira, M. E. eds. Herpetologia no Brasil II. Belo Horizonte, Sociedade Brasileira de Herpetologia. pp. 201-221.

Pontes, J. A. L; Pontes, R. C. \& Rocha, C. F. D. 2009. The snake community of Serra do Mendanha, in Rio de Janeiro State, southeastern Brazil: composition, abundance, richness and diversity in areas with different conservation degrees. Brazilian Journal Biology 69:795-804.

Primack, R. B. \& Rodrigues, E. 2001. Biologia da Conservação. Londrina, Planta Editora. 328p.

Prudente, A. L. C. \& Santos-Costa, M. C. 2005. Checklist of snakes from Ferreira Penna Scientific Station, Eastern Amazonia, Pará State, Brazil. Boletim do Museu Paraense Emílio Goeldi 3:203-208.

Prudente, A. L. C.; Maschio, G. F.; Yamashina C. E. \& SantosCosta, M. C. 2007. Morphology, reproductive biology and diet of Dendrophidion dendrophis (Schlegel, 1837) (Serpentes, Colubridae) in Brazilian Amazon. South American Journal of Herpetology 2:53-58.

Rocha, W. A. \& Prudente, A. L. C. 2010. The snake assemblage of Parque Nacional de Sete Cidades, State of Piauí, Brazil. South American Journal of Herpetology 5:132-142.

Rodrigues, M. T. 2003. Herpetofauna da Caatinga. In: LeAL, I. R.; Tabarelli, M. \& Silva, J. M. C. eds. Ecologia e Conservação da Caatinga. Recife, Universidade Federal de Pernambuco, p. 181-236.

Ron, S. 2000. Biogeographic area relationships of lowland Neotropical rainforest based on raw distributions of vertebrate groups. Biological Journal of the Linnean Society 71:379-402.
Roze, J. A. 1996. Coral snakes of the America: Biology, identification and venoms. Florida, Krieger Publishing Company. 328p.

Santos-Costa, M. C.; Prudente, A. L. C. \& Di-Bernardo, M. 2006. Reproductive biology of Tantilla melanocephala (Linnaeus, 1758) (Serpentes, Colubridae) from Eastern Amazonia, Brazil. Journal of Herpetology 40:556-559.

Santos-Costa, M. C.; Maschio, G. F. \& Prudente, A. L. C. 2015. Natural history of snakes from Floresta Nacional de Caxiuanã, eastern Amazonia, Brazil. Herpetology Notes 8:69-98.

Sawaya, R. J.; Marques, O. A. V. \& Martins, M. 2008. Composition and natural history of a Cerrado snake assemblage at Itirapina, São Paulo State, Southeastern Brazil. Biota Neotropica 8: 129-151.

Scheibler, D. L. \& Christoff, A. U. 2007. Associações de habitat de pequenos mamíferos no sul do Brasil e uso de pelotas de regurgitação de aves de rapina para inventariar uma fauna local. Brazilian Journal Biology 67:619-625.

Shmida A. \& Wilson M.V. 1985. Biological determinants of species diversity. Journal of Biogeography 12(1):1-20.

Siqueira, D. M.; Nascimento, L. P. \& Santos-Costa, M. C. 2012. Feeding Biology of Boddaert's Tropical Racer, Mastigodryas boddaerti (Serpentes, Colubridae) from the Brazilian Amazon. South American Journal of Herpetology 7(3):226-232.

Sneath, P. H. A. \& Sokal, R. R. 1973. Numerical taxonomy. San Francisco, Freeman and Co. 573p.

Strüssmann, C. 2000. Herpetofauna. In: Ministério do Meio Ambiente ed. Fauna silvestre na região do Rio Manso - MT. Brasília, Editora IBAMA, Centrais Elétricas do Norte do Brasil, p. 153-189.

ToKeshi, M. 1999. Species Coexistence: ecological and evolutionary perspective. London, Blackwell. 468p.

Townsend, C. R.; Scarsbrook, M. R. \& Doledec, S. 1997. The intermediate disturbance hypothesis, refugia, and biodiversity in streams. Limnology and Oceanography 42:938-949.

Tozetti, A. M. \& Martins, M. 2008. Habitat use by the South-America rattlesnake (Crotalus durissus) in South-eastern Brazil. Journal of Natural History 49:19-20.

Tuomisto, H. \& Ruokolainen, K. 1997. The role of ecological knowledge in explaining biogeography and biodiversity in Amazonia. Biodiversity and Conservation 6:347-357.

VitT, L. J. \& VANGILDER, L. D. 1983. Ecology of a snake community in Northeastem Brazil. Amphibia-Reptilia 4:273-296.

Zanella, N. \& Cechin, S. Z. 2006. Taxocenose de serpentes no planalto médio do Rio Grande do Sul, Brasil. Zoologia 23:211-217.

Zug, G. R.; Vitt, L. J. \& Caldwell, J. P. 2001. Herpetology. An introductory biology of amphibians and reptiles. California, Academic Press. 630p. 